\title{
Entrepreneurship Workshop in Kampung Nelayan's Community, Medan Belawan District
}

\author{
Hanny Siagian, William, Nasrul Efendia) \\ Study Program of Management, Faculty of Business, Mikroskil University, Medan, Indonesia \\ a)Corresponding Author: nasrul.efendi@mikroskil.ac.id
}

\begin{abstract}
Approximately 600 families inhabit the Kampung Nelayan of Medan Belawan District; most of them work as fishermen. The people of Kampung Nelayan have limited facilities and relatively low knowledge of entrepreneurship which caused an inability to maximize the potential of marine natural resources and mangrove forest resources. Entrepreneurship workshop activities are carried out to equip the public to have a good knowledge of entrepreneurship, which is expected to generate and increase the spirit of entrepreneurship in utilizing and managing the potential of natural resources into high selling value products. The activities were carried out using a quasi-experimental one-group pretest-posttest approach. The results of the pretest and post-test were used to measure changes in participants knowledge. The results of the outreach activities showed that there was a change in participants entrepreneurial knowledge, marked by an increase in the average number of pretest and post-test scores. However, in terms of the number of individual scores, there were variations in participants' knowledge, namely increasing, constant, and decreasing. Following up on this result, it is necessary to conduct entrepreneurship assistance and workshops to implement knowledge in managing businesses and marketing them to improve the economy.
\end{abstract}

Keywords: Entrepreneurship, mangrove, quasi-experimental, resources

\section{INTRODUCTION}

Poverty is a problem that has not yet been properly resolved in Indonesia, and this is indicated by the presence of some people under the poverty line who have not been able to fully meet basic needs such as food, clothing and shelter. Poverty is the inability to meet the minimum standards of basic human needs. In his book Supriatna (1997) says there are five standard characteristics of poverty, namely 1) do not have their own production factors, 2) do not have the possibility to obtain production assets with their own strength, 3) the level of education is generally low, 4) many of them do not have facilities, 5) among them are relatively young and do not have adequate skills or education.

Kampung Nelayan is located in Medan Belawan district, Medan City, North Sumatra Province. In the north, it is bordered by a Mangrove Forest, in the south by the Belawan River, in the east by the Malacca Strait, and in the west by a mangrove forest. It is inhabited by approximately 1,000 people with 600 families, with the majority of their activities being fishermen. The life of the people in the Kampung Nelayan is still classified as poor. They live on the sea, with houses made of inadequate boards. Garbage seems to be very familiar with their lives, which is carried by seawater at high tide and sticks around the community's living area. In fact, Kampung Nelayan has the potential of marine natural resources and mangrove forests that can be processed and developed. However, the condition of the Kampung Nelayan's population has not been able to process and produce and market processed products optimally. This is not because they do not have production assets, facilities or education and skills, but it is suspected that it is caused by a lack of education or knowledge about entrepreneurship in depth.

In general, the residents of Kampung Nelayan work as fishermen who feel comfortable with the conditions they experience every day, relying on fish catches to meet their daily needs, even though marine natural resources and mangrove forests are available around them which can be utilized and developed into a product that is worth selling. Based on the results of the pre-survey conducted, one of the suspected causes is the lack of knowledge and skills possessed to 
increase the value of available natural resources, or it can be said that the most basic thing is that the entrepreneurial spirit of the community is still very low. Therefore, entrepreneurship education efforts are needed in the community, especially in the young age group. This workshop is expected to be able to foster a creative, innovative and independent entrepreneurial spirit that will bring new alternatives to people's livelihoods.

\section{METHOD}

The workshop activities in Kampung Nelayan were carried out by providing knowledge education related to entrepreneurial disciplines, especially those related to the mindset and entrepreneurial spirit. The activity was carried out using a quasi-experiment one-group pretestposttest approach. Quasi-Experiment: One-Group Pretest-Posttest Design is a quasi-experiment where a group is measured and observed before and after the treatment is given (Fraenkel et al., 2012). Some researchers (Lombardini et al., 2018; Privitera \& Delzell, 2019; William \& Hita, 2019) have implemented this method, especially in educational research, as it is designed to allow them to conduct an experiment when randomization is impractical and classroom limitation (Privitera \& Delzell, 2019).

The experiment was conducted in the following steps

1. Beginning with a pretest to find out how much the knowledge of the participants about the topics.

2. Deliver a direct explanation of the material for each topic in front of the participants.

3. Conduct a post-test at the end of the workshop to determine changes in participants' knowledge after participating in the training activity.

The workshop's activity was carried out in the form of lectures (face to face), question and answer, and discussions with the participants with the following topics:

1. Become an entrepreneur

2. Action Orientation.

3. Thinking Change

4. Entrepreneurship

\section{RESULTS}

The entrepreneurship workshop was attended by 12 (twelve) female participants, aged 35-50 years and domiciled in the Kampung Nelayan. The participants took part in the workshop activities with great enthusiasm and curiosity about the extension materials presented. This is based on the results of the evaluation of activities presented in the following table:

Table 1. Pretest and posttest scores of entrepreneur workshop in kampung nelayan

\begin{tabular}{rlccc}
\multirow{2}{*}{ No. } & Participants & \multicolumn{2}{c}{ Correct Score } & Score \\
\cline { 3 - 4 } 1 & Evi Mariani & Pretest & Post-Test & Differences \\
2 & Susanti & 25 & 24 & -1 \\
3 & Lasiah & 22 & 22 & 0 \\
4 & Hamidah & 16 & 20 & 0 \\
5 & Aisyah & 21 & 22 & 0 \\
6 & Imah & 16 & 22 & 1 \\
7 & Nurmala & 21 & 23 & 2 \\
8 & Juliani & 22 & 22 & 0 \\
9 & Mardiyah & 21 & 22 & 1 \\
10 & Siti Hadijah & 23 & 23 & 0 \\
11 & Rubiah & 21 & 21 & 0 \\
12 & Aslamiah & 22 & 21 & -1 \\
\hline \multicolumn{2}{r}{ Average } & 20,7 & 21,5 & 0,8 \\
\hline
\end{tabular}

In Table 1 above, the results of the evaluation of workshop activities are obtained in terms of the pretest and post-test scores of participants' answers to each question on the test. The test 
consists of 25 questions, a score of 1 if the answer is correct and a score of 0 if the answer is wrong. The total range of answer scores is $0-25$.

The average pretest score was 20.7, with the highest score of 25 as many as 1 of 12 participants (8.33\%) and the lowest score of 16 as many as 2 of 12 participants (16.66\%). The average post-test score was 21.5, with the highest score of 24 as many as 1 of 12 participants (8.33\%) and the lowest score of 16 as many as 1 of 12 participants (8.33\%). Then, Table 1 also shows that there is an increase in the number of post-test scores in 4 participants (33.33\%), there is no increase in the number of post-test scores in 6 participants $(50.00 \%)$, and there is a decrease in the number of post-test scores. -test on 2 participants $(16,67 \%)$.

\section{DISCUSSION}

In general, it can be said that the results of the evaluation of extension activities showed a change in participants' knowledge about entrepreneurship which was marked by an increase in the average number of post-test scores compared to the pretest, but when viewed from the number of the individual score, there was a variation of changes in participants' knowledge, namely there increasing, constant and decreasing. The participant's knowledge is more dominant with the number of fixed and decreasing scores. This condition is caused by differences in the absorption ability of participants in understanding the extension material, which is influenced by education level, intelligence, media exposure about Entrepreneurship.

Being an entrepreneur needs to have a dream and always be action-oriented. Entrepreneurs should not only dream, speak, think or talk but are required to dare to see opportunities, face risks, uncertainties, limitations and continue to think about changes in accordance with the demands of changes that occur in the social and economic environment. This is in line with what was stated by R.G. McGrath \& I. MacMillan (2000) "Humans with an entrepreneurial mindset execute, namely taking action and realizing what they think rather than analyzing new ideas to death".

Entrepreneurs must also always think productive so that they are able to seize opportunities to produce or add value to a product, both goods and services offered to the market later. Kasali et al. (2010) stated that "The mindset of an entrepreneur stands out in many ways. In the matter of consumption, an entrepreneur is productive, not consumptive. An entrepreneur is also always trying to "find new ways" to increase the utility of resources efficiently. An entrepreneur tends to be a job creator rather than just a job seeker. All of these characters are caused by the total number of positive, creative, financial, and productive mindsets he has.

A business built without a productive mindset will only become a small business that will not grow and develop properly. Without a productive mindset, an entrepreneur is very difficult to face the challenges and obstacles faced when running a business where these challenges and obstacles can only be overcome with the right decisions and actions to overcome them resulting from the positive, creative and innovative mindset of an entrepreneur.

\section{CONCLUSIONS AND RECOMMENDATIONS}

The workshop activity showed a change in participant's knowledge about entrepreneurship which was marked by an increase in the average number of post-test scores compared to pretest scores. Activities are also generally expected to provide benefits for a better life when participants understand and implement the knowledge that an entrepreneur must possess when running a business so that the business can generate maximum income and can develop in the future and be able to generate a good source of income. so that it is expected to improve the quality of life for the residents of fishing villages.

Following up on the results of outreach activities, it is necessary to conduct entrepreneurship assistance and workshops so that participants can implement knowledge in managing businesses and marketing them in order to improve the participants' economy. 


\section{ACKNOWLEDGMENTS}

Thanks to the Faculty of Business, Mikroskil University, for funding this community service following the contract for the 2020 fiscal year so that this community service can be carried out. Thanks also to the residents of Kampung Nelayan and Mrs Sarawiyah for providing supports during the workshop.

\section{REFERENCES}

Fraenkel, J. R., E. Wallen, N., \& Hyun, H. H. (2012). How to Design And Evaluate Research In Education (8th ed.). Mc Graw Hill.

Kasali, R., Nasution, A. H., Purnomo, B. R., Ciptarahayu, A., Mirzanti, I. R., Rustiadi, S., Daryanto, H. K., \& Mulyana, A. (2010). Modul Kewirausahaan untuk Program Strata 1. Rumah Perubahan.

Lombardini, C., Lakkala, M., \& Muukkonen, H. (2018). The impact of the flipped classroom in a principles of microeconomics course: evidence from a quasi-experiment with two flipped classroom designs. International Review of Economics Education, 29(August 2016), 14-28. https://doi.org/10.1016/j.iree.2018.01.003

Privitera, G. J., \& Delzell, L. A. (2019). Quasi-Experimental and Single-Case Experimental Designs. In Research Methods for Education (pp. 333-370). SAGE Publications, Inc.

R.G. McGrath, \& I. MacMillan. (2000). The Entrepreneurial Mindset. Harvard Business School Press.

Supriatna. (1997). Kemiskinan: Teori, Fakta, dan Kebijakan. Impac.

William, \& Hita. (2019). Mengukur Tingkat Pemahaman Pelatihan PowerPoint Menggunakan Quasi-Experiment One-Group Pretest-Posttest. Jurnal SIFO Mikroskil (2019) 20(1) 71-80, 20(1), 71-80. 


\section{APPENDIX}

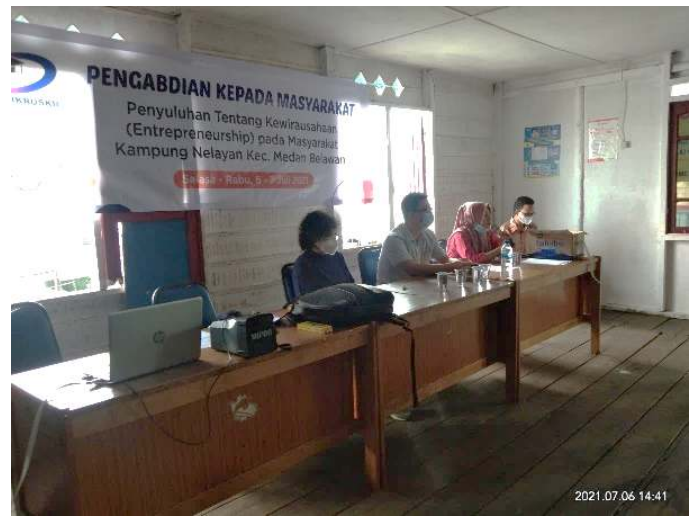

Figure 1. The Opening Session

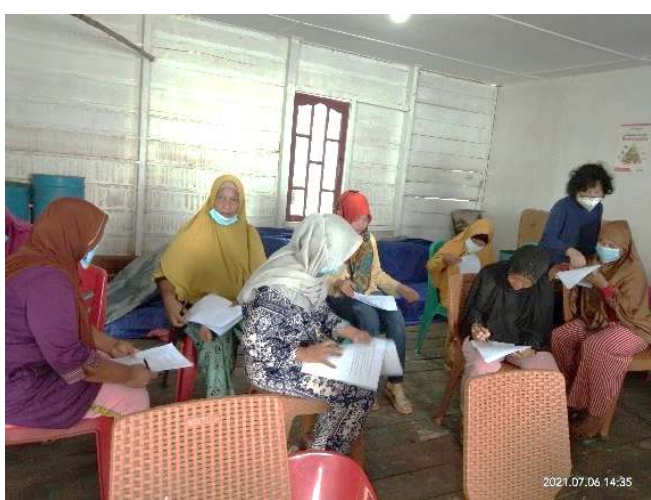

Figure 3. Pretest and Posttest Activity

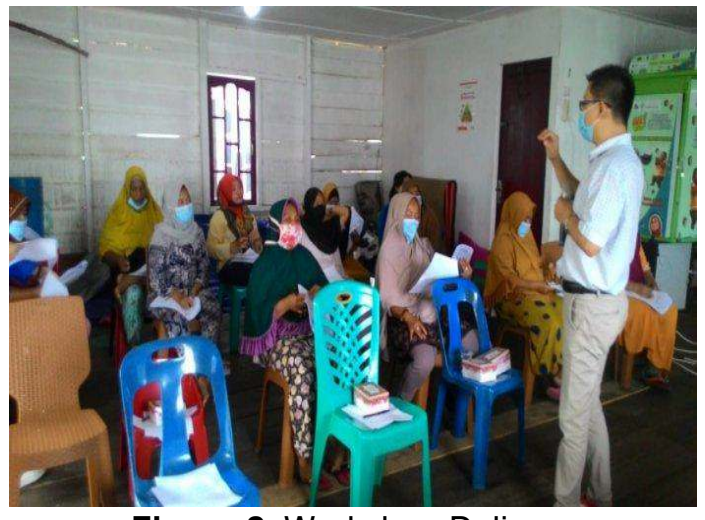

Figure 2. Workshop Delivery

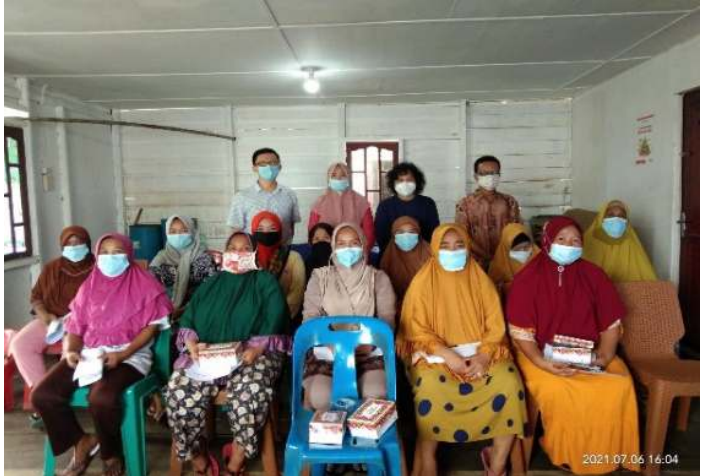

Figure 4. The Closing Session 